\title{
Morphology and yield potential of sweet potato (Ipomoea batatas L.) as influence by NPK fertilizer rates and vine cutting length in Jos Plateau State, Nigeria
}

\author{
Mudi, A. ${ }^{1}$, Nwadike, C. ${ }^{2 \star}$, Oladejo, A. O. ${ }^{3}$, Dinchi, P. T. ${ }^{1}$, Gloria, P. M. ${ }^{1}$, Ojochogu, D. ${ }^{1}$, Ruth, A. \\ J.1, Mathias, O.4, Alamanjo. C. C. ${ }^{2}$ and Yakubu, M. T. ${ }^{5}$ \\ 1Department of Crop Production Technology, Federal College of Forestry, Jos, Nigeria. \\ ${ }^{2}$ Department of Agricultural Technology, Federal College of Forestry, Jos, Nigeria. \\ ${ }^{3}$ Department of Pest Management Technology, Federal College of Forestry, Jos, Nigeria. \\ ${ }^{4}$ Department of Forestry Technology, Federal College of Forestry, Jos, Nigeria. \\ ${ }^{5}$ Savanna Forestry Research Station, Zaria, Nigeria. \\ *Corresponding author. Email: chrisnwadike1@gmail.com
}

Copyright (C) 2021 Mudi et al. This article remains permanently open access under the terms of the Creative Commons Attribution License 4.0, which permits unrestricted use, distribution, and reproduction in any medium, provided the original work is properly cited.

Received 3rd March, 2021; Accepted 27th April, 2021

\begin{abstract}
The experiment was carried out in the demonstration farm of Federal College of Forestry Jos during the 2019 farming season to determine the effects of NPK fertilizer rates and vine cutting lengths on the growth and yield of sweet potato. The treatments include, three rates of NPK fertilizer $(0,0.2$ and $0.4 \mathrm{~kg})$ allocated to the main plot and two vine cutting lengths of $(30$ and $40 \mathrm{~cm})$ in the sub plot in $3 \times 2$ factorial split plot design. The parameters assessed includes; number of branches, length of vine, leaf count, leaf area index and vine girth at 2, 4, 6, 8 and 10 weeks after fertilizer application (WAFA) and tuber count, tuber length, and yield weight at harvest. The parameters were subjected to analysis of variance and the means separated using the LSD (Least significant difference) at $(p \leq 0.05)$. The results on the number of branches shows significant difference at 2 and 6 (WAFA) and at 4 WAFA for both treatments and positive interaction at 8 WAFA. Vine length showed no statistical difference at 4 WAFA, but significance at 2 and 8 WAFA with positive interaction at same weeks. The results on leaf count showed significance across the weeks with fertilizer rates and at 2 WAFA with vine cuttings with no interactions across the trend. The leaf area index showed no statistical difference with all the treatments as indicated. The vine girth showed significant difference across the weeks with fertilizer rates, and at 10 WAFA with the vine cuttings with no interactions. The yield parameters showed significance and positive interaction across with both treatments on tuber count, tuber weight and tuber length respectively. In conclusion, these results indicated that planting sweet potato in Jos plateau with a fertilizer rates of $\left(0.4 \mathrm{~kg} / 2 \mathrm{~m}^{2}\right.$ experimental plot) and $40 \mathrm{~cm}$ vine length could impact the growth and yield positively.
\end{abstract}

Keywords: Factorial, fertilizer rates, sweet potato, vine length, weeks after fertilizer application (WAFA).

\section{INTRODUCTION}

Sweet potato (Ipomoea batatas $L$ ) is an herbaceous, warm weather creeping plant belonging to the family convolvulaceae and genus Ipomoea. The family is made up 45 genera and 1,000 species, out of which only Ipomoea batatas is of economic importance to man and animals (Woolfe, 1992). Sweet potato is known to be among the world's most important, versatile and under exploited food crops (International potato center (CIP),
2017). With more than 133 million tonnes in annual production, sweet potato currently ranks as the seventh most important food crop on a fresh-weight basis in developing countries after rice, wheat, maize and cassava (CIP, 2017., Jan et al., 2015).

The crop is grown in many countries globally but production primarily occurs in tropical and sub-tropical areas where it is important as stable food in the diet of 
many people. Sweet potato is one of the most important root and tuber crops in sub-Saharan African with both domestic and industrial uses and its nutritional value far exceeds that of Yam, cocoyam and cassava (Prakash et al., 2016).

According to CIP (2017), average yield in several countries is well below the average yield of 15 tonnes per hectares for developing countries as a whole, and these in turn are well below the crop's potential. However, in the last decades, there has been a positive growth rate for sweet potato production in China, as well as a number of developing countries.

China tops the list of world largest producers of sweet potato with 70570.94 metric tons, Nigeria is second largest producers with 3916.69 metric tons annually. In Africa, Nigeria is first with 3.72 tonnes/ ha (FAOSTAT, 2016).

In Nigeria, cultivation of sweet potato and its utilization have expanded to all the ecological zones within the past decades, 200,000-400,000 hectares of land are under sweet potato cultivation. Yield of root tubers have increased from farmer's pre-research era of above 3 tons per hectares due to availability of improved varieties (NRCRI, 2009 as cited in Mbanaso, 2010).

Sweet potato is traditionally used as boiled root tubers eaten with stew, it is pounded and eaten as fufu with soup, its dried, milled for sweetening of porridge, sliced into chips, process into flour for making chin chin, bread and alcoholic beverages.

Cultivation of sweet potato has received a boost in the last few decades due to available of improved clones to aid growth and yield, also improvement in the nutrient composition of the crop has endeared farmers in other climes like china and India to increase their production level so much that it has not only increased their (GDP) from export, it has also improved their dietary intake. In Nigeria and other developing nations and particularly the study area despite these improvements on the crop, its cultivation is still on subsistence level with the evidence of low yield and poor tuber qualities due to the following; Misconception of the crop been a vehicle for diabetes and dysentery, lack of wide spread cultivation due to limitation in the utilization of the crop, preference of other root and tuber crops and cereals. Similarly, cultivation is also hampered due to lack of adoption of the precision of it agronomic practices, like its planting dates, fertilizer application rates, weeding regimes, choice of planting vine length and planting without a definite pattern of management and harvesting procedure (NRCRI, 2009 as cited in Mbanaso, 2010).

Vine cutting length is one of the most important agronomic practice that must be adopted in the cultivation of sweet potato. The apical and middle portion of the vine is found to be the best for getting higher root yield, bottom portions usually thick and woody, sometimes fail to establish and there is a greater chance of weevil incidence due to proximity with the known portion where sweet potato weevil multiplies. A vine length of 20 to $40 \mathrm{~cm}$ with a least 3 to 5 nodes is found to be ideal for optimum storage root production (Nair 2006). Similar results were reported by NRCRI in Nigeria in the research work on vine cutting length adopted 5-nodes cutting length (NRCRI, 2009 as cited in Mbanaso, 2010).

In recent time, the production rate of sweet potato has been on the decrease despite its numerous economic and nutritional values. This decrease in production of sweet potato has been traced to the poor nutrient status of the soil where this crop is grown. High rainfall, crop removal, rapid mineralization of soil organic matter (SOM) and excessive cultivation of land due to increase in human population are responsible for this decrease (IITA, 1995).

Sweet potato removes appreciable quantities of plant nutrients, hence incorporation of considerable amount of organic manure at the time of planting is recommended to maintain soil productivity. Application of manures has significant impact on growth and root yield of sweet potato. Soils low in organic matter content have to be supplied with organic manure at 5 to 10 tons' $^{\text {ha-1 }}$ to ensure proper develo-pment of storage root. Application of Nitrogen (N) increased the root yield. However, high amount of $\mathrm{N}$ application encourages vine growth rather than storage root development (Satapathy et al., 2005 and Salawu and Muktar 2008). A Moderate dose of 50 to $75 \mathrm{kgNha}^{-1}$ is optimum for root production in sweet potato (Sebastiani et al., 2006), higher levels of $\mathrm{N}$ sometimes depressed the root yield.

Quality characters, apart from storage root yield of sweet potato, were found to be influenced by nitrogen application. Continues use of fertilizer $\mathrm{N}$ may, in some situation have detrimental effects on root quality. Therefore, use of organic sources of $\mathrm{N}$ is essential to improve the quality characters like starch, vitamin $C$ and $\beta$ carotene which are more important than percentage content (Nedunchezhiyan and Ray 2010). Sweet potato response to phosphorus $(p)$ is very low, doses of $25-50 \mathrm{~kg}$ $\mathrm{P}_{2} \mathrm{O}_{5} \mathrm{ha}^{-1}$ is considered optimum for sweet potato (Akinrinde, 2006).

Potassium ( $k$ ) is a major key element essential on the synthesis and translocation of carbohydrates from the tops to the roots. A moderate dose of 75 to $100 \mathrm{~kg} \mathrm{~K}$ 20 is recommended for sweet potato, besides, quality characters like starch and protein content were found to increase with increased K level (Biswal 2008). Generally, Onwudike, (2010), reported that application of NPK fertilizer at the rates of $100 \mathrm{~kg}$ per hectare improved plant growth, tuber yield and soil fertility.

\section{MATERIALS AND METHODS}

\section{Study site}

The research was carried out at the teaching and research farm of Federal College of Forestry Jos, Plateau during the 2019 cropping seasons. Jos is located on latitude $8^{\circ} 8^{\prime} \mathrm{N}$ and $10^{\circ} 10^{\prime} \mathrm{N}$ and longitude $8^{\circ} 20^{\prime} \mathrm{E}$ with an elevation of $1250 \mathrm{~m}$ above sea level (asl). The climate is generally 
humid tropical with annual rainfall of 146 to $148 \mathrm{~cm}$ and an annual mean temperature of $25^{\circ} \mathrm{C}$ (Olowolafe, 2002).

\section{Soil sample collection and analysis}

Composite soil samples of the experimental site at the depth of 0 to $30 \mathrm{~cm}$ using soil auger were collected. The samples were air dried, sieved through a $2 \mathrm{~mm}$ mesh and analyzed for texture, $\mathrm{pH}$, organic matter, total nitrogen, available phosphorus, exchangeable calcium, potassium, sodium and cation exchange capacity (CEC).

\section{Experimental design}

The experiment was laid out in $3 \times 2$ factorial design with fertilizer rates $\left(0,0.2\right.$ and $0.4 \mathrm{~kg} / 2 \mathrm{~m}^{2}$ experimental plot) and two vine length cuttings $(30$ and $40 \mathrm{~cm}$ ) in six treatments combination fixed in a Randomized Complete Block Design (RCBD) replicated three times each. The vine length cuttings were planted at specific planting spacing of $30 \mathrm{~cm}$. Fertilizer treatments was applied at 2 split doses at 4 and 8 weeks after planting. The field was kept weed free throughout the experiment. The sweet potato variety (TIS 8164) was obtained from National Root Crop Research Institute Kuru, Jos, Plateau State.

\section{Data collection}

Data were collected at 2, 4, 6, 8, and 10 weeks after fertilizer application (WAFA) on:

Number of branches: This parameter was determined by counting the number of branches found on each of five sampled plants in plot and recorded.

Leaf count: This parameter was determined by counting the number of leaves on the five sampled plants on each replication and recorded.

Vine length: The vine length was determined by measuring the length of the vine in the five sampled plants in each of the replication using a meter rule and expressed in centimeter.

Vine girth: This was done by measuring the distance round the girth of the vine using the digital caliper in millimeter $(\mathrm{mm})$ on five tagged plants and the results recorded.

Leaf area index (LAI): The leaf area index was determined by measuring the leaf area in meters on the five tagged plants and the corresponding land area in meters and the results recorded.

Number of roots: The number of roots per plants was determined by counting the number of tubers produced by the five sampled plants in the plot at harvest.
Root length: This was determined by measuring the length of the tuber of five tagged plants in a plot using the meter rule at harvest.

Root diameter: The parameter was determined by measuring the distance round the tuber using a digital caliper.

Root weight: This was determined by weighing the tubers from the five sampled plants from each plot using a scale balance at harvest.

Root yield in kg: The yield from each treatment was harvested and weighed, the value expresses in kilograms per hectare.

\section{Data analysis}

Data were analyzed using the Generalized Linear Model (GML) procedure of statistical Analysis System (SAS) package version 9.1 and the mean separation was done using the Least Significant Difference (LSD) at 5\% probability level.

\section{RESULTS}

The Table 1 showed the physical and chemical properties of soil of the study site. The results on the number of branches showed significant $(p \leq 0.05)$ difference with the fertilizer rates at 2 and 6 (WAFA) with both $0.4 \mathrm{~kg} / 2 \mathrm{~m}^{2}$ given the highest mean values of 2.27 and 3.33 , respectively. Vine cutting length however, showed significant difference at 4 WAFA with $30 \mathrm{~cm}$ given highest mean value (2.56). There was positive interaction of the treatments at 8 WAFA with $0.4 \mathrm{~kg} / 2 \mathrm{~m}^{2} \times 40 \mathrm{~cm}$ given the highest mean value (3.53) (Table 2).

Vine length cuttings in Table 3 showed no statistical difference at 4 WAFA but on 2, 68 and 10 WAFA with 0.2 $\mathrm{kg} / 2 \mathrm{~m}^{2}$ having a dominant highest mean value with the fertilizer rates. Similarly, significance was observed on vine length cuttings at 2 and 8 WAFA with $40 \mathrm{~cm}$ having the highest mean values of 51.47 and 95.96 , respectively. With positive interaction at 2 and 8 WAFA with $0.4 \mathrm{~kg} / 2 \mathrm{~m}^{2}$ $\times 40 \mathrm{~cm}$ and $0.2 \mathrm{~kg} / 2 \mathrm{~m}^{2} \times 40 \mathrm{~cm}$ having the highest mean values of 55.96 and 106.46 , respectively.

The results on leaf count in Table 4 indicated that significant difference was observed across the weeks with $0.2 \mathrm{~kg} / 2 \mathrm{~m}^{2}$ having the highest mean values of 41.30 . $59.70,59.06,61.85$ and 62.83 across. The vine cutting length however shows a significant difference only at 2 WAFA with $40 \mathrm{~cm}$ having the highest mean value of 39.96 , with no interactions across the trend. The interactions of the treatments showed no difference statistically throughout but $40 \mathrm{~cm}$ vine length did better with different fertilizer rates compared to $30 \mathrm{~cm}$. 
Table 1. Soil composition of the experimental site at depth of soil 0-30 cm.

\begin{tabular}{lc}
\hline Soil composition & Obtained values \\
\hline $\mathrm{pH}$ & 6.30 \\
$\mathrm{~N} \%$ & 0.035 \\
$\mathrm{OM} \%$ & 2.07 \\
$\mathrm{P} \mathrm{ppm}$ & 2,8 \\
& \\
Exchangeable bases mMol/100g & \\
$\mathrm{Na}$ & 0.10 \\
$\mathrm{Ca}$ & 1.5 \\
$\mathrm{Mg}$ & 0.45 \\
& \\
Exchangeable Acidity mMol/100g & \\
$\mathrm{K}$ & 2.0 \\
$\mathrm{H}+$ & 3.5 \\
$\mathrm{AL} 3+$ & $\mathrm{Nil}$ \\
$\mathrm{CEC}$ mMol/10\% & 6.34 \\
Clay\% & 6.16 \\
Silt\% & 8.0 \\
Sand\% & 85.84 \\
Texture & Loamy soil \\
\hline
\end{tabular}

Table 2. Effects of fertilizer rates and vine cutting length on branch count at 2, 4, 6, 8, 10 weeks after fertilizer application (WAFA)

\begin{tabular}{|c|c|c|c|c|c|}
\hline \multirow{2}{*}{ Parameters } & \multicolumn{5}{|c|}{ Treatments } \\
\hline & 2WAFA & 4WAFA & 6WAFA & 8WAFA & 10WAFA \\
\hline \multicolumn{6}{|c|}{ Fertilizer rates $(\mathrm{kg})$} \\
\hline 0.0 & $1.67^{b}$ & 2.30 & $2.56^{\mathrm{ab}}$ & 3.07 & 3.30 \\
\hline 0.2 & $2.10^{\mathrm{a}}$ & 2.47 & $2.96^{\mathrm{ab}}$ & 3.10 & 3.47 \\
\hline 0.4 & $2.29^{b}$ & 2.40 & $3.33^{\mathrm{a}}$ & 3.37 & 3.53 \\
\hline SE & 0.16 & 0.17 & 0.17 & 0.16 & 0.18 \\
\hline LSD & ** & NS & * & NS & NS \\
\hline \multicolumn{6}{|c|}{ Vine Length $(\mathrm{cm})$} \\
\hline 30 & $2.04^{a}$ & $2.56^{\mathrm{a}}$ & 3.13 & 3.29 & 3.42 \\
\hline 40 & $1.98^{\mathrm{a}}$ & $2.22^{\mathrm{b}}$ & 2.97 & 3.07 & 3.44 \\
\hline SE & 0.13 & 0.13 & 0.14 & 0.13 & 0.14 \\
\hline LSD & NS & * & NS & NS & NS \\
\hline \multicolumn{6}{|c|}{ Interactions Fert. $X$ vine length } \\
\hline $0.0 \times 30$ & 1.73 & 2.53 & 3.20 & $3.33^{\mathrm{ab}}$ & 3.40 \\
\hline $0.0 \times 40$ & 1.60 & 2.07 & 2.53 & $2.80^{b}$ & 3.20 \\
\hline $0.2 \times 30$ & 2.20 & 2.67 & 3.13 & $3.33^{a b}$ & 3.47 \\
\hline $0.2 \times 40$ & 2.00 & 2.27 & 2.80 & $2.87^{b}$ & 3.47 \\
\hline $0.4 \times 30$ & 2.20 & 2.47 & 3.06 & $3.20^{\mathrm{ab}}$ & 3.40 \\
\hline $0.4 \times 40$ & 2.33 & 2.33 & 3.60 & $3.53^{a}$ & 3.67 \\
\hline SE & 0.22 & 0.23 & 0.24 & 0.22 & 0.25 \\
\hline LSD & NS & NS & NS & * & NS \\
\hline
\end{tabular}

Mean in a column having the same superscript are not significant. NS $=$ Not significant at $p \leq .05 ;{ }^{*}=$ Significant at $p \leq .05$.

The leaf area index showed no statistical difference with all the treatments as indicated in Table 5. However, the vine girth showed significant difference across the weeks with both 0.2 and $0.4 \mathrm{~kg} / 2 \mathrm{~m}^{2}$ showing similar trend. At 10 
Table 3. Effects of fertilizer rates and vine cutting length on vine length at 2, 4, 6, 8, 10 weeks after fertilizer application (WAFA).

\begin{tabular}{|c|c|c|c|c|c|}
\hline \multirow{2}{*}{ Parameters } & \multicolumn{5}{|c|}{ Treatments } \\
\hline & 2WAFA & 4WAFA & 6WAFA & 8WAFA & 10WAFA \\
\hline \multicolumn{6}{|c|}{ Fertilizer rates } \\
\hline 0.0 & $40.79^{c}$ & 74.94 & $76.76^{b}$ & $79.51^{b}$ & $61.29^{a}$ \\
\hline 0.2 & $46.22^{\mathrm{b}}$ & 98.85 & $101.66^{a}$ & $101.44^{\mathrm{a}}$ & $101.70^{\mathrm{a}}$ \\
\hline 0.4 & $48.97^{a}$ & 98.90 & $92.59^{a}$ & 93.15 & $93.85^{\mathrm{ab}}$ \\
\hline SE & 0.22 & 6.02 & 5.42 & 5.50 & 15.10 \\
\hline LSD & ** & NS & ** & ** & * \\
\hline \multicolumn{6}{|c|}{ Vine cutting length } \\
\hline 30 & $39.18^{b}$ & 85.15 & 87.09 & $86.77^{\mathrm{b}}$ & 79.97 \\
\hline 40 & $51.47^{a}$ & 92.82 & 93.58 & $95.96^{a}$ & 91.26 \\
\hline SE & 1.03 & 0.23 & 4.43 & 4.49 & 12.33 \\
\hline LSD & ** & NS & NS & * & NS \\
\hline \multicolumn{6}{|l|}{ Fert. x VL } \\
\hline $0.0 \times 30 \mathrm{~cm}$ & $33.25^{d}$ & 70.71 & 73.07 & $70.55^{\mathrm{b}}$ & 50.45 \\
\hline $0.0 \times 40 \mathrm{~cm}$ & $48.33^{c}$ & 79.17 & 80.44 & $88.47^{\mathrm{ab}}$ & 72.13 \\
\hline $0.2 \times 30 \mathrm{~cm}$ & $42.31^{\mathrm{c}}$ & 93.14 & 94.71 & $96.47^{a}$ & 95.63 \\
\hline $0.2 \times 40 \mathrm{~cm}$ & $50.12^{\mathrm{b}}$ & 104.55 & 108.60 & $106.40^{\mathrm{a}}$ & 107.77 \\
\hline $0.4 \times 30 \mathrm{~cm}$ & $41.97^{b}$ & 91.59 & 93.48 & $93.29^{a b}$ & 93.82 \\
\hline $0.4 \times 40 \mathrm{~cm}$ & $55.96^{a}$ & 94.75 & 91.71 & $93.00^{\mathrm{ab}}$ & 93.89 \\
\hline SE & 1.456 & 8.509 & 7.67 & 7.78 & 21.36 \\
\hline LSD & ** & NS & NS & * & NS \\
\hline
\end{tabular}

Mean in a column having the same superscript are not significant. NS $=$ Not significant at $p \leq 0.05 ;{ }^{*}=$ Significant at $p \leq 0.05$.

Table 4. Effects of fertilizer rates and different vine length cuttings on leaf count at 2, 4, 6, 8, 10 weeks after fertilizer application (WAFA).

\begin{tabular}{|c|c|c|c|c|c|}
\hline \multirow{2}{*}{ Parameters } & \multicolumn{5}{|l|}{ Treatments } \\
\hline & 2WAFA & 4WAFA & 6WAFA & 8WAFA & 10WAFA \\
\hline \multicolumn{6}{|c|}{ Fertilizer rates(kg) } \\
\hline 0.0 & $32.17^{b}$ & $43.67^{b}$ & $45.36^{b}$ & $46.30^{\mathrm{b}}$ & $49.20^{b}$ \\
\hline 0.2 & $41.31^{\mathrm{a}}$ & $59.70^{a}$ & $59.06^{a}$ & $61.83^{\mathrm{a}}$ & $62.83^{a}$ \\
\hline 0.4 & $39.43^{a}$ & $48.43^{b}$ & $49.67^{\mathrm{ab}}$ & $52.23^{\mathrm{ab}}$ & $53.63^{b}$ \\
\hline SE & 2.49 & 4.20 & 4.15 & 4.18 & 4.03 \\
\hline LSD & ** & ** & * & * & * \\
\hline \multicolumn{6}{|c|}{ Vine length cuttings $(\mathrm{cm})$} \\
\hline $30 \mathrm{~cm}$ & $35.31^{b}$ & 49.67 & 50.13 & 52.07 & 54.09 \\
\hline $40 \mathrm{~cm}$ & $39.96^{a}$ & 51.53 & 52.6 & 54.84 & 56.36 \\
\hline SE & 2.03 & 3.43 & 3.39 & 3.41 & 3.29 \\
\hline LSD & * & NS & NS & NS & NS \\
\hline \multicolumn{6}{|c|}{ Fert. rates $\times$ VL } \\
\hline $0.0 \times 30$ & 29.80 & 39.07 & 40.93 & 40.73 & 42.53 \\
\hline $0,0 \times 40$ & 34.53 & 48.27 & 49.80 & 51.87 & 55.87 \\
\hline $0.2 \times 30$ & 39.13 & 62.27 & 59.80 & 64.40 & 65.87 \\
\hline $0.2 \times 40$ & 43.47 & 57.13 & 58.33 & 59.27 & 59.80 \\
\hline $0.4 \times 30$ & 37.00 & 47.67 & 49.67 & 51.07 & 53.87 \\
\hline $0.4 \times 40$ & 41.87 & 49.20 & 49.67 & 53.40 & 53.40 \\
\hline SE & 3.51 & 5.95 & 5.87 & 5.91 & 5.70 \\
\hline LSD & NS & NS & NS & NS & NS \\
\hline
\end{tabular}

Mean in a column having the same superscript are not significant. NS = Not significant at $p \leq 0.05 ;{ }^{*}=$ Significant at $p \leq 0.05$. 
Table 5. Effects of NPK fertilizer rates and vine cutting on leaf area index at 2, 4, 6, 8, 10 weeks after fertilizer application (WAFA).

\begin{tabular}{|c|c|c|c|c|c|}
\hline \multirow{2}{*}{ Parameters } & \multicolumn{5}{|c|}{ Treatments } \\
\hline & 2WAFA & 4WAFA & 6WAFA & 8WAFA & 10WAFA \\
\hline \multicolumn{6}{|c|}{ Fertilizer rates } \\
\hline 0.0 & 0.62 & 0.64 & 0.63 & 0.65 & 0.65 \\
\hline 0.2 & 0.67 & 0.63 & 0.63 & 0.64 & 0.66 \\
\hline 0.4 & 0.62 & 0.63 & 0.62 & 0.61 & 0.58 \\
\hline SE & 0.06 & 0.06 & 0.06 & 0.06 & 0.07 \\
\hline LSD & NS & NS & NS & NS & NS \\
\hline \multicolumn{6}{|c|}{ Vine cutting length } \\
\hline 30 & 0.63 & 0.67 & 0.67 & 0.67 & 0.65 \\
\hline 40 & 0.65 & 0.59 & 0.59 & 0.61 & 0.62 \\
\hline SE & 0.06 & 0.05 & 0.05 & 0.05 & 0.05 \\
\hline LSD & NS & NS & NS & NS & NS \\
\hline \multicolumn{6}{|c|}{ Fert. rate $\times$ VL } \\
\hline $0.0 \times 30$ & 0.61 & 0.64 & 0.64 & 0.65 & 0.69 \\
\hline $0.0 \times 40$ & 0.62 & 0.64 & 0.63 & 0.66 & 0.62 \\
\hline $0.2 \times 30$ & 0.66 & 0.68 & 0.68 & 0.68 & 0.66 \\
\hline $0.2 \times 40$ & 0.69 & 0.58 & 0.58 & 0.60 & 0.66 \\
\hline $0.4 \times 30$ & 0.61 & 0.68 & 0.69 & 0.66 & 0.60 \\
\hline $0.4 \times 40$ & 0.63 & 0.57 & 0.56 & 0,56 & 0.57 \\
\hline SE & 0.08 & 0.09 & 0.09 & 0.09 & 0.09 \\
\hline LSD & NS & NS & NS & NS & NS \\
\hline
\end{tabular}

Mean in a column having the same superscript are not significant. NS = Not significant at $p \leq 0.05$; ${ }^{*}=$ Significant at $p \leq 0.05$.

WAFA, however, the vine cuttings were significant statistically with $40 \mathrm{~cm}$ having a marginal higher mean value. There was no interaction between the fertilizer rates and vine cuttings length across the weeks (Table 5). The results on the vine girth indicated that there was significance $(p \leq 0.05)$ on fertilizer rates throughout the weeks. In a similar vein, vine cutting length and interactions showed no difference statistically as shown in Table 6.

Fertilizer rates had impact on the yield parameters with significant difference on tuber count, tuber weight and tuber length with $0.4 \mathrm{~kg} / 2 \mathrm{~m}^{2}$ having the highest mean values $(5.10,10.10$ and 0.31$)$ compared to $0.2 \mathrm{~kg} / 2 \mathrm{~m}^{2}$ and $0.0 \mathrm{~kg} / 2 \mathrm{~m}^{2}$. Vine cutting length had significant impact on tuber count and tuber weight with $0.4 \mathrm{~kg} / 2 \mathrm{~m}^{2}$ having the highest mean values (4.31 and 0.29). There were interactions across the yield parameters with $40 \mathrm{~cm}$, which did better with varied rates of NPK fertilizer rates compared to $30 \mathrm{~cm}$ (Table 7 ).

\section{DISCUSSION}

The results obtained indicate that different rates of fertilizer and vine cutting lengths could influence the growth and yield parameters of sweet potato (Ipomoea batatas L.) in the study area. Table 1 presents the results of soil composition of the study area which has a textural class of sandy loam, the soil has low $\mathrm{pH}$, organic carbon, total $\mathrm{N}$, available $\mathrm{P}$ as well as exchangeable cations. The result on branch count in Table 2 showed that there was significant $(p \leq 0.05)$ difference with different fertilizer rates at 2 and 6 WAFA with $0.4 \mathrm{~kg} / 2 \mathrm{~m}^{2}$ given higher mean value of 2.27 and 3.33. This result confirms the result of Onwudike (2010) who reported that higher rates of fertilizer application improved sweet potato growth characters. Similarly, vine length cuttings on branch count show significant difference $(p \leq 0.05)$ only at 4 WAFA, but $30 \mathrm{~cm}$ vine length cutting from observations had better effects on the branch count across the trend with only $40 \mathrm{~cm}$ better off at 10 WAFA (3.44). The result supported the work of Nair (2006) who stated that a vine cutting length of 20 to $40 \mathrm{~cm}$ with at least 3 to 5 nodes is ideal for optimum growth and development of sweet potato plant.

The results of fertilizer rates on length of vine indicates that there was significant $(p \leq 0.05)$ difference across the weeks with $0.4 \mathrm{~kg} / 2 \mathrm{~m}^{2}$ having the highest mean value. Vine cutting length showed significant $(p \leq 0.05)$ difference at 2 and 8 WAFA and $40 \mathrm{~cm}$ cutting length had higher mean value (51.47 and 91.26) compared to $30 \mathrm{~cm}$ (Table 3 ). This result confirmed the work of Ray et al. (2001) and Nedunchezhiyan et al. (2012) who reported that there is an increase in length of vine due to increase in the length of cuttings. 
Table 6. Effects of NPK fertilizer rates and vine cutting length on Vine girth at 2, 4, 6, 8, 10 weeks after fertilizer application (WAFA).

\begin{tabular}{|c|c|c|c|c|c|}
\hline \multirow{2}{*}{ Parameters } & \multicolumn{5}{|c|}{ Treatments } \\
\hline & 2WAFA & 4WAFA & 6WAFA & 8WAFA & 10WAFA \\
\hline \multicolumn{6}{|c|}{ Fertilizer rates $(\mathrm{kg})$} \\
\hline 0.0 & $0.27^{b}$ & $0.30^{\mathrm{b}}$ & $0.31^{b}$ & $0.32^{b}$ & $0.32^{\mathrm{b}}$ \\
\hline 0.2 & $0.32^{\mathrm{a}}$ & $0.32^{\mathrm{a}}$ & $0.33^{a}$ & $0.33^{a}$ & $0.33^{a}$ \\
\hline 0.4 & $0.32^{\mathrm{a}}$ & $0.32^{\mathrm{a}}$ & $0.33^{\mathrm{a}}$ & $0.33^{\mathrm{a}}$ & $0.33^{\mathrm{a}}$ \\
\hline SE & 0.01 & 0.06 & 0.005 & 0.002 & 0.003 \\
\hline LSD & * & * & * & * & * \\
\hline \multicolumn{6}{|c|}{ Vine cutting length } \\
\hline 30 & 0.29 & 0.32 & 0.32 & 0.33 & 0.32 \\
\hline 40 & 0.31 & 0.32 & 0.32 & 0.33 & 0.33 \\
\hline SE & 0.09 & 0.004 & 0.004 & 0.002 & 0.003 \\
\hline LSD & NS & NS & NS & NS & NS \\
\hline \multicolumn{6}{|c|}{ Fert. rates $\times \mathrm{VL}$} \\
\hline $0.0 \times 30$ & 0.25 & 0.29 & 0.29 & 0.32 & 0.31 \\
\hline $0.0 \times 40$ & 0.29 & 0.31 & 0.31 & 0.32 & 0.32 \\
\hline $0.2 \times 30$ & 0.31 & 0.33 & 0.32 & 0.32 & 0.33 \\
\hline $0.2 \times 40$ & 0.32 & 0.32 & 0.33 & 0.33 & 0.33 \\
\hline $0,4 \times 30$ & 0.33 & 0.32 & 0.33 & 0.34 & 0.33 \\
\hline $0,4 \times 40$ & 0.32 & 0.33 & 0.33 & 0.33 & 0.34 \\
\hline SE & 0.02 & 0.008 & 0.007 & 0.003 & 0.004 \\
\hline LSD & NS & NS & NS & NS & NS \\
\hline
\end{tabular}

Mean in a column having the same superscript are not significant. NS $=$ Not significant at $p \leq 0.05 ;{ }^{*}=$ Significant at $p \leq 0.05$.

Table 7. Effects of NPK fertilizer rates and vine cutting length on the yield parameters at harvest.

\begin{tabular}{lccc}
\hline \multirow{2}{*}{ Parameters } & & Treatments & \\
\cline { 2 - 4 } Fertilizer rates & Tuber count & Tuber length & Tuber weight \\
0.0 & $3.13^{\mathrm{b}}$ & & \\
0.2 & $3.40^{\mathrm{b}}$ & $4.90^{\mathrm{b}}$ & $0.20^{\mathrm{b}}$ \\
0.4 & $5.10^{\mathrm{a}}$ & $5.80^{\mathrm{b}}$ & $0.21^{\mathrm{b}}$ \\
SE & 0.41 & $10.10^{\mathrm{a}}$ & $0,31^{\mathrm{a}}$ \\
LSD & $*$ & 0.58 & 0.06 \\
& & $*$ & $*$ \\
Vine cutting length & & & \\
30 & $3.44^{\mathrm{b}}$ & & $0.21^{\mathrm{b}}$ \\
40 & $4.31^{\mathrm{a}}$ & $6.90^{\mathrm{a}}$ & $0.29^{\mathrm{a}}$ \\
SE & 0.58 & $6.98^{\mathrm{a}}$ & 0.03 \\
LSD & $*$ & 0.47 & $*$ \\
Fert. $\times$ VL & & $N S$ & \\
$0.0 \times 30$ & & & $0.16^{\mathrm{c}}$ \\
$0.0 \times 40$ & $2.80^{\mathrm{b}}$ & & $0.19^{\mathrm{bc}}$ \\
$0.2 \times 30$ & $3.47^{\mathrm{b}}$ & $5.07^{\mathrm{b}}$ & $0.16^{\mathrm{c}}$ \\
$0.2 \times 40$ & $3.33^{\mathrm{b}}$ & $4.71^{\mathrm{b}}$ & $0.34^{\mathrm{a}}$ \\
$0.4 \times 30$ & $3.47^{\mathrm{b}}$ & $5.01^{\mathrm{b}}$ & $0.31^{\mathrm{cb}}$ \\
$0.4 \times 40$ & $4.20^{\mathrm{b}}$ & $6.62^{\mathrm{b}}$ & $0.35^{\mathrm{a}}$ \\
SE & $6.00^{\mathrm{a}}$ & $10.63^{\mathrm{a}}$ & 0.05 \\
LSD & 0.57 & $9.61^{\mathrm{a}}$ & $*$ \\
\hline
\end{tabular}

Mean in a column having the same superscript are not significant. NS $=$ Not significant at $p \leq 0.05 ;{ }^{*}=$ Significant at $p \leq 0.05$. 
Table 4 presents the result of fertilizer rates and cutting length on the leaf count. The result showed that fertilizer rates show significant $(p \leq 0.05)$ difference across the weeks with $0.4 \mathrm{~kg} / 2 \mathrm{~m}^{2}$ producing the higher mean values compared to $0.2 \mathrm{~kg} / 2 \mathrm{~m}^{2}$. Similarly, on vine cutting lengths, significant $(p \leq 0.05)$ difference was recorded at 2 WAFA, with $40 \mathrm{~cm}$ cutting length given the highest mean value (39.96). This result supported the work of Essilfie et al. (2016) who reported that increase in leaf number was due to longer vine cutting length which in turn produced more branches and leaves.

The result on leaf area index (Table 5) indicated that there was no significant $(p \geq 0.05)$ difference across the trends on both fertilizer rates and vine cutting lengths. Observations however showed that fertilizer rate of 0.2 $\mathrm{kg} / 2 \mathrm{~m}^{2}$ performed better than the $0.4 \mathrm{~kg} / 2 \mathrm{~m}^{2}$. Vine cutting lengths on the other hand did better with $40 \mathrm{~cm}$ except at 2 WAFA where $30 \mathrm{~cm}$ cutting length did marginally better. This result supported the findings of Brobbey (2015) who reported that growth and yield parameters tend to increase with increase in the propagules length used of which 30 $\mathrm{cm}$ was recommended.

Vine girth indicated in Table 6 showed that significant $(p \leq 0.05)$ difference was observed across the weeks with fertilizer rates 0.2 and $0.4 \mathrm{~kg} / 2 \mathrm{~m}^{2}$ showing the same mean value. Vine cutting length did not show statistical difference except at 10 weeks after fertilizer application and $40 \mathrm{~cm}$ showed a marginal higher mean value (0.33) compared to $30 \mathrm{~cm}(0.32)$. This result supports the work of Prasad (1989) who reported that vine cutting length of $40 \mathrm{~cm}$ is most appropriate for propagation as evidenced on the increase in both vegetative and yield parameters of sweet potato.

Yield parameters showed that fertilizer rates had significant difference $(p \leq 0.05)$ on both tuber count, tuber length, and tuber weight / yield at harvest with $0.4 \mathrm{~kg} / 2 \mathrm{~m}^{2}$ fertilizer rate show the highest means value $(5.10,10.10$ and 0.31 ) on both parameters compared to $0.2 \mathrm{~kg} / 2 \mathrm{~m}^{2}$ and $0.0 \mathrm{~kg} / 2 \mathrm{~m}^{2}$ which had $(3.40,5.80$ and 0.21$)$ and $(3.13,4.10$ and 0.20 ) respectively (Table 7 ). This confirms the work of onwudike (2010) who reported that higher rates of fertilizer application improve potato yield and its attendant parameters due to availability of more nutrients. The vine cutting length was significant $(p \leq 0.05)$ on tuber count and tuber weight at $40 \mathrm{~cm}$ vine cutting length which had (4.31 and 0.21 ) compared to $30 \mathrm{~cm}$ which had (3.44 and 0.21) respectively. This confirms the work of Essilfie et al. (2016) who reported that tuber yield tends to increase with increase in the length of vine cutting used.

\section{Conclusion and Recommendation}

The results obtained from this study indicated that planting sweet potato in Jos plateau with a fertilizer rates of 400 $\mathrm{kg} / \mathrm{ha}\left(0.4 \mathrm{~kg} / 2 \mathrm{~m}^{2}\right.$ plot) and $40 \mathrm{~cm}$ vine cutting length could impact the growth and yield positively. However, more experiments comparing various fertilizer rates and vine cutting lengths are needed for probable conclusion, recommendation and adoption in the study area considering the fact that $0.2 \mathrm{~kg} / 2 \mathrm{~m}^{2}$ and $40 \mathrm{~cm}$ and $30 \mathrm{~cm}$ performed incredibly well at some growth parameters.

\section{CONFLICT OF INTEREST}

The authors declare that they have no conflict of interest.

\section{REFERENCES}

Akinrinde, E. A. (2006). Phosphorus fertilization effect on dry matter production and biomass partitioning in sweet potato (Ipomoea batatas) grown on an acidic loamy sand Alfisol. Journal of Food Agriculture Environment, 4(3-4), 99-104.

Biswal, S. (2008). Response of sweet potato to irrigation and fertility levels. PhD thesis, Orissa Agricultural University and Technology Bhubaneswar, India

Brobbey, A. (2015). Growth, yield and quality factors of sweet potato (Ipomoea batatas L.) as influenced by seed bed type and fertilization. Kwame Nkrumah University of Science and Technology. (M.Phil. thesis). 75p.

CIP International Potato Centre (2017). CIP sweet potato facts. Production, Utilization, Consumption, Feed use. Retrieved from https://cipotato.org/

Mbanaso, E. D. (2010). Adoption and disadoption of sweet potato production and processing technology by farmers in SouthEastern Nigeria. Ph.D thesis, Department of Agricultural Extension University of Nigeria, Nsukka, Nigeria.

Essilfie, M. E., Dapaah, H. K., Tevor, J. W., \& Darkwa, K. (2016). Number of nodes and part of vine cutting effect on the growth and yield of sweetpotato (Ipomoea batatas (L.) Lam) in transitional zone of Ghana. International Journal of Plant and Soil Science, 9(5), 1-14.

FAO (2016). Food and Agricultural Organization Annual Report Rome Italy.

IITA (1995). Annual report fallow system for sustainable farming. International Institute for Tropical Agriculture. p. 44.

Jan, L., Moses, N., Sara, Q., \& Monica, P. (2015). Potato and sweet potato in Africa transforming the value chains for food and nutritional security. CAB International.

Nair, G. M. (2006). Agro-techniques and planting material production in sweet potato. In: Byju, G. (ed.). Quality planting material production in Tropical Tuber crops. CTCRI.

Nedunchezhiyan, M., Byju, G., \& Jata, S. K. (2012). Sweet potato agronomy. Fruit, Vegetable and Cereal Science and Biotechnology, 6(1), 1-10.

Olowolafe, E. A. (2002). Soil parent materials and soil properties in two separate catchment areas on the Jos Plateau, Nigeria. Geography Journal, 56(3), 201-212.

Onwudike, S. U. (2010). Effectiveness of cow dung and mineral fertilizer on soil properties, nutrient uptake and yield of sweet potato (Ipomoea batatas) in Southeastern Nigeria. Asian Journal of Agricultural Research, 4(3), 148-154.

Prakash, P., Avinash, K., Devesh, R., \& Debdutt, B. (2016). Economic analysis of sweet potato farming and marketing Odisha. Journal of Root Crops, 42(2), 163-167.

Prasad, M. (1989). Yield of sweet potato as affected by planting method and vine length. J. Root Crops, 15(1), 63-64

Ray, C. S., Anthony, E., Singh, R., Kar, G., \& Vermah, N. (2001). Sources and relationship in sweet potato under different irrigation regimes. Journal of Root Crops, 27(1)164-168. 
Salawu, I. S., \& Mukhtar, A. A. (2008). Reducing the dimension of growth and yield characters of sweet potato varieties as affected by varying rates of organic fertilizer. Asia Journal of Agricultural Research, 2(1), 41-44.

Satapathy, M. R., Sen, H., Chattopadhyay, A., \& Mothapatra, B. K. (2005). Dry matter accumulation, growth rate and yield of sweet potato cultivars as influenced by nitrogen and cutting management, Journal of Root Crops, 31(1), 129-132.
Sebastiani, S. K., Mgonja, A., Urio, F., \& Ndondi, T. (2006, November). Response of sweet potato to application of nitrogen and phosphorus fertilizer, agronomic and economic benefits in the Northern highlands of Tanzania. In 14th Triennial Symposium of International Society of Tropical Root Crops (pp. 20-26).

Woolfe, J. A. (1992). Sweet potato: an untapped food resource. Cambridge University Press. 